$10-2017$

\title{
Unpacking the Mind of Evil: A Sociological Perspective on the Role of Intent and Motivations in Genocide
}

\author{
Timothy Williams \\ University of Marburg \\ Dominik Pfeiffer \\ Universität Hamburg
}

Follow this and additional works at: https://digitalcommons.usf.edu/gsp

\section{Recommended Citation}

Williams, Timothy and Pfeiffer, Dominik (2017) "Unpacking the Mind of Evil: A Sociological Perspective on the Role of Intent and Motivations in Genocide," Genocide Studies and Prevention: An International

Journal: Vol. 11: Iss. 2: 72-87.

DOI:

http://doi.org/10.5038/1911-9933.11.2.1485

Available at: https://digitalcommons.usf.edu/gsp/vol11/iss2/8

This Articles is brought to you for free and open access by the Open Access Journals at Digital Commons @ University of South Florida. It has been accepted for inclusion in Genocide Studies and Prevention: An International Journal by an authorized editor of Digital Commons @ University of South Florida. For more information, please contact digitalcommons@usf.edu. 


\title{
Unpacking the Mind of Evil: A Sociological Perspective on the Role of Intent and Motivations in Genocide
}

\author{
Timothy Williams \\ University of Marburg \\ Marburg, Germany \\ Dominik Pfeiffer \\ Universität Hamburg \\ Hamburg, Germany
}

\section{Introduction}

Genocide is the crime of crimes. What distinguishes the most prominent of all international statutory offences from other forms of macro violence ${ }^{1}$ is the dolus specialis, the special intent, that informs perpetrators when they commit certain acts of violence (structural or physical). The genocide convention of 1948 states: "genocide means any of the following acts committed with intent to destroy, in whole or in part, a ... group, as such." ${ }^{2}$ By definition, intent is more than a simple will to kill or to perform other acts of violence-it is the will to do violence to certain human beings because they are perceived or real members of a specific group, ultimately with the goal to destroy the group. ${ }^{3}$

Beyond these rather general conceptual boundaries the role and meaning of intent has always been heavily disputed. On the one hand, intentionalists stress the importance of intent from the very beginning of the mass violence; on the other hand, functionalists emphasize structural dynamics driven by other motivations. ${ }^{4}$ Along the same lines, Powell, referring to Moses, identified a liberal and post-liberal divide. ${ }^{5}$ Representatives of the former view "conceive of genocide as the intended action of a coherent agent." 6 This agent is chiefly the state, under whose umbrella elites and foot soldiers both act intentionally alike. Post-liberal views "conceive of genocide as a structural process that does not require any intending agent."7 Deviating from liberal individualism, collectives and structures are foregrounded in a way that intent and intentional action of single perpetrators fade from the spotlight almost completely. In a similar fashion, jurisprudence and legal scholars distinguish between a purposed-based and a knowledge-based approach: "Adoption of a so-called purpose-based approach, which dwells on intent, results in a focus on individual offenders and their own personal motives. A so-called knowledge-based approach, on the other hand, directs the inquiry towards the plan or policy of a state or similar group, and highlights the collective dimension of the crime of genocide." 8

${ }^{1}$ Herbert Jäger, Makrokriminalität: Studien zur Kriminalität kollektiver Gewalt (Frankfurt am Main: Suhrkamp, 1989).

${ }^{2}$ United Nations, Convention on the Prevention and Punishment of the Crime of Genocide, December 9, 1948 (UN Doc. A/RES/260(III)[A-C]).

${ }^{3}$ Throughout this essay, we take a wide definition of genocide as a basis. The definition of the Genocide Convention (supra fn. 2) establishes genocide as a legal fact and is widely accepted in both legal and political discourse. However, researchers, especially in the social fact and is widely accepted in both legal and political discourse. However, researchers, especially in the social sciences and humanities, revealed its various shortcomings with regard to the analysis of genocide as an empirical phenomenon. Law practitioners continue to use the UN definition despite its constraints because its international legal acceptance allows the prosecution of participants in genocide. As social scientists, however, our aim is to approach the topic more analytically than legally, broadening our understanding of genocide to embrace more groups than those specified in the UN convention and to take wider approaches to mass violence in the context of genocide into account and simply speak of structural and physical violence (instead of 'killing' or 'forcibly transferring children' etc.). See Claudia Card, "Genocide and Social Death," Hypatia 18, no. 1 (2003), 63-79; Martin Shaw, What is Genocide? (Cambridge, UK: Polity Press, 2007).

${ }^{4}$ Samuel Totten and Paul R. Bartrop, Dictionary of Genocide (Westport: Greenwood Press, 2008), 214-215.

${ }^{5}$ Christopher Powell, "What Do Genocides Kill? A Relational Conception of Genocide," Journal of Genocide Research 9, no. 4 (2007), 527-547; A. Dirk Moses, "Conceptual Blockages and Definitional Dilemmas in the 'Racial Century': Genocides of Indigenous Peoples and the Holocaust," Patterns of Prejudice 36, no. 4 (2002): 7-36.

${ }^{6}$ Powell, What Do Genocides Kill?, 528

${ }^{7}$ Ibid.

${ }^{8}$ William A. Schabas, An Introduction to the International Criminal Court (Cambridge, UK: Cambridge University Press, 2011). 
However, the polarisation of the debate has increasingly been seen as deeply problematic because it leads to either overstating or understating intent. The individualism of liberal and purposed-based thinking and the intentionalist perspective ultimately leads to a strong emphasis on a monolithic version of intent. There is a tendency to assume a strong and direct relationship between genocidal intent and genocidal praxis that does not withstand any serious criminological analysis. In contrast, post-liberal, functionalist and knowledge-based approaches downplay the role of intent to a point where it dissolves in social collectives and socio-political structures. Thus, the distinction from other forms of mass violence becomes blurred. Ultimately, this position encounters the problem of formulating a distinct concept of genocide that distinguishes it from other types of mass violence.

Against this backdrop, however, scholars such as Kimura ${ }^{9}$, Ambos $^{10}$ or Jensen ${ }^{11}$ have already developed more nuanced concepts and thoughts about the role of intent in genocide. From a criminological perspective, Ambos argues for a combination of the above-mentioned approaches, thereby taking especially different roles and classes of actors into account. He concludes that "purpose based intent should only be upheld with regard to the top- and mid-level perpetrators while for the low-level perpetrators' knowledge of the genocidal context should suffice."12 Also arguing for a more differentiated view, Jensen examined the role of intent in legal prosecution and its shortcoming that there are juridical expectations of what he calls consistency in individuals' behaviour in order to infer intent. ${ }^{13}$ Jensen shows elegantly how consistency is not a necessary precondition for intent in the cases of Goran Jelisić and Josef Schwammberger. Verdeja shows that current research tends to opt for a more dynamic view on intent by focusing on its emergence rather than taking it as pre-given. ${ }^{14}$ Finally, these new conceptual tendencies correspond to developments in history and historiography, where the different motivations and intentions have been the focus of research for quite some time. ${ }^{15}$

Generally following this new perspective on intent in genocide, we want to add some conceptual sociological thought to the debate in order to strengthen its theoretical foundations. ${ }^{16}$ Drawing on social movement theory and frame analysis we want to support juridical discussions and contribute to the current criminological thinking on genocide. In this regard we will combine macrosociological observations on collective action with microsociological and sociopsychological insights into the attitudes and the behaviour of individuals. Our main argument is as follows: We argue that intent needs to be primarily located in the cognitive frames that open up a joint action context for the collective action of genocide. Low-level perpetrators commit their individual crimes as part of a state-sponsored social movement whose existence depends on a cognitive frame in which genocidal intent plays a crucial role. But while "ordinary men"17 may at times explicitly share a general genocidal intent, they usually act due to a host of more profane motivations. We draw here on the work of Williams whose inter-contextual model flags many other motivations

${ }^{9}$ Akio Kimura, "Genocide and the Modern Mind: Intention and Structure," Journal of Genocide Research 5, no. 3 (2003), 405420.

${ }^{10}$ Kai Ambos, "Criminologically Explained Reality of Genocide, Structure of the Offence and the 'Intent to Destroy' Requirement," in Collective Violence and International Criminal Justice: An Interdisciplinary Approach, ed. Alette Smeulers (Antwerpen: Insertia, 2010), 153-173.

${ }^{11}$ Olaf Jensen, "Evaluating Genocidal Intent: The Inconsistent Perpetrator and the Dynamics of Killing," Journal of Genocide Research 15, no. 1 (2013), 1-19.

${ }^{12}$ Ambos, "Criminologically Explained Reality of Genocide," 153.

${ }^{13}$ Jensen, "Evaluating Genocidal Intent."

${ }^{14}$ Ernesto Verdeja, “The Political Science of Genocide: Outlines of an Emerging Research Agenda," Perspectives on Politics 10, no. 2 (2012), 307-321.

${ }^{15}$ Paul Gerhard, Die Täter der Shoah: Fanatische Nationalsozialisten oder ganz normale Deutsche? (Göttingen: Wallstein Verlag, 2002).

${ }^{16}$ Although this paper is sociological in nature, at the micro level discussed in section 4 there are many influences from social psychology, anthropology and criminology, too.

${ }^{17}$ Christopher Browning, Ordinary Men: Reserve Police Battalion 101 and the Final Solution in Poland (New York: Harper, 1993); for a critique see Peter Longerich, Holocaust. The Nazi Persecution and Murder of the Jews (Oxford: Oxford University Press, 2010), 186. 
besides ideology and intent for individuals' motivation to participate in genocide. ${ }^{18}$ Thus, genocidal intent can be realised without direct perpetrator intent. In this sense, we combine a purposebased approach (which we mainly locate at the macro level) with a knowledge-based approach (which we attribute to the micro level of individual perpetration). We distance ourselves from the simple linear liberal/ intentionalist thinking of a straight and monolithic relationship of intent and outcome, while also avoiding a post-liberal/functionalist view that negates any distinction of genocide from other forms of mass violence.

This article is structured as follows: The first two sections elaborate on our sociological concept of genocide as collective action by a genocidal social movement. We start with a theoretical derivation on how intent is to be situated in cognitive frames; frames that constitute these social movements and secure their existence as such. These conceptual statements at the macro-level of genocide are followed by some remarks on how genocidal frames create a possibility for genocide at the micro level. We complement this first step of connection between the macro and the micro level with a reflection on how individual perpetrators perceive this framed intent. Next, we elaborate on the types of motivations low-level perpetrators may have when they act in a framed context. We then briefly discuss how the resulting individual acts of violence aggregate in genocide.

\section{Genocidal Frames}

In this first section, we start our argument by laying out our concept of genocide at the macro level. We will argue that genocidal action is action by a state-sponsored social movement that is working towards the destruction of a specific group as such, thereby being constituted and instructed by a collective frame. In the process of framing, state level actors develop genocidal intent and realign the frame accordingly. This rather abstract theoretical formulation requires further elaboration and we will tackle the different terms and aspects step by step.

Let us begin by stressing the rather simple fact that genocide is a social phenomenon. Although a single person may hypothetically commit them, ${ }^{19}$ genocides have always been perpetrated by a large amount of different people-instigators, low-, mid-, and high-level perpetrators, bystanders, and more-interacting with each other. The Holocaust, Rwanda, Armenia, or Cambodia-in historical cases, a whole range of actors such as political leaders and elites, civil servants and common people, military personnel and paramilitaries all fulfil different roles when they engage together in atrocities, often bringing together state actors such as armed forces and police with state-sanctioned paramilitaries such as the SS or SA in Nazi Germany, the interhamwe in Rwanda, the Teşkilati Mahsousa during the Armenian genocide or the Khmer Rouge chhlop. These groups were then supplemented by civilian supporters in various roles, ranging from broad societal participation in Rwanda and Armenia to quite limited civilian involvement in Cambodia and the Holocaust. In this sense, we can say that genocidal action is collective action, i.e. the formation and action of a social movement that is working towards a common goal in a joint action context.

Usually, social movements are mostly associated with noble causes such as fighting for human rights or against climate change. But by common definition, a social movement is just a form of collective action that shows some resilience and stability over a certain period of time. ${ }^{20}$ The demands, claims and goals of the people participating in it can be virtually anything. It is not even said that all social movements engage in so-called contentious politics against the state, as one might initially think. Quite on the contrary, state-sponsored social movements have gained some attention in research and the discourse on collective action. Su defines them as "popular movement[s] initiated and endorsed by the central leadership of the state and organized by the

\footnotetext{
${ }^{18}$ Timothy Williams, "The Complexity of Evil: A Multi-Faceted Approach to Genocide Perpetration," Zeitschrift für Friedens- und Konfliktforschung 3, no. 1 (2014), 71-98.

${ }^{19}$ In the Jelisic case, the International Criminal Tribunal for the former Yugoslavia famously coined the idea of a 'lone genocidal maniac'. See note 8 above. While the idea certainly is of some interest for jurisprudence, it still resembles a legal intellectual game. At least to us it is of no further interest for the investigation at hand because it would reduce it to the question of whether a single person does or does not have intent.

${ }^{20}$ Sidney Tarrow, Power in Movements: Social Movements and Contentious Politics, 2nd ed. (Cambridge, UK: Cambridge University Press, 2008), 2.
} 
government's apparatuses." ${ }^{21}$ When it comes to genocide, we clearly speak of this special kind of social movement, as the state and its military and security apparatus almost always play a major role in genocide. ${ }^{22}$ Looking back in history, Schabas states that "genocide was generally, although perhaps not exclusively, committed under the direction or, at the very least, with the benign complicity of the State where it took place. Usually, the crime was executed as a quite overt facet of State policy, particularly within the context of war or colonial conquest." 23

Michael Mann even goes so far as proclaiming a direct connection between the emergence of new states and genocide, particularly evident in how interwoven genocidal policies became with nation-building projects in the late Ottoman Empire and in the breakup of Yugoslavia. ${ }^{24}$ So we can enhance the definition presented above by saying that genocidal action is action by a statesponsored social movement that is working towards a common goal in a joint action context.

The goal of genocide is the destruction of a specific group as such; a group that is singled out by the state-sponsored social movement. Perpetrators then try to achieve this goal by applying structural violence (e.g. racist laws that force people to live under miserable conditions in ghettos) and physical violence (e.g. mass murder). Of course, these settings of mass violence each consist of specific individual acts-from policing the ghetto to picking up a rifle and shooting someone. So we can say that genocidal action is action by a state-sponsored social movement that is working towards the destruction of a specific group as such in a joint action context.

Following this definition, it remains to elaborate on the joint action context. Our argument is that this is the place where we must locate intent. To justify this argument, we refer to frame analysis theory ${ }^{25}$ Its foundational work was developed by Goffman ${ }^{26}$ and picked up and refined by Snow and others. ${ }^{27}$ Today, this approach represents one of the most influential sociological theories on explaining collective action. While the research focus in the literature on social movements has been on resource mobilization and political opportunities for a long time, ${ }^{28}$ frame analysis highlights the relevance of "meaning work-the struggle over the production of mobilizing and countermobilizing ideas and meanings" ${ }^{29}$ - for and through social movements. Relying on vast empirical data, the theory states that neither the command of resources (e.g. money, media, and power) nor an advantageous political situation (not even the direct support by the state) suffices to explain the formation and the collective action of social movements. What is needed is a cognitive frame, which we can understand as a "interpretative schemata that simplifies and condenses 'the world out there' by selectively punctuating and encoding objects, situations, events, experiences, and sequences of actions within one's present or past environment." ${ }^{\prime 30}$

${ }^{21}$ Yang Su, "State-Sponsored Social Movements," in The Wiley-Blackwell Encyclopedia of Social Movements, ed. David A. Snow et al. (Oxford: John Wiley \& Sons, 2013).

${ }^{22}$ Peter B. Owens and David A. Snow, "Genocide and Social Movements," in The Wiley-Blackwell Encyclopedia of Social Movements, ed. David A. Snow et al. (Oxford: John Wiley \& Sons, 2013).

${ }^{23}$ William A. Schabas, Genocide in International Law: The Crimes of Crimes, 2nd ed. (Cambridge, UK: Cambridge University Press, 2009), 1.

${ }^{24}$ Michael Mann, The Dark Side of Democracy: Explaining Ethnic Cleansing (Cambridge, UK: Cambridge University Press, 2005).

${ }^{25}$ It should be noted that we are not the first to introduce this theoretical approach into analysing mass violence. Others have impressively demonstrated the value of frame analysis for understanding the actions and behaviour of perpetrators. However, they used frame analysis for the detailed analysis of soldiers acting in war, while we want to present a more conceptual argument on genocide. See Sönke Neitzel, Abgehört: Deutsche Generäle in britischer Kriegsgefangenenschaft, 1942-1945 (Berlin: Propyläen, 2005).

${ }^{26}$ Erving Goffman, Frame Analysis: An Essay on the Organization of Experience (Boston: Northeastern University Press, 1986).

${ }^{27}$ David A. Snow et al., "Frame Alignment Processes, Micromobilization, and Movement Participation," American Sociological Review 51, no. 4 (1986), 464-481.

${ }^{28}$ David A. Snow, "Framing Processes, Ideology, and Discursive Fields," in The Blackwell Companion to Social Movements, ed. David A. Snow et al. (Malden: Blackwell, 2004).

${ }^{29}$ David A. Snow and Robert D. Benford, "Framing Processes and Social Movements: An Overview and Assessment," Annual Review of Sociology 26 (2000), 611-639.

${ }^{30}$ David A. Snow and Robert D. Benford, "Master Frames and Cycles of Protest," in Frontiers in Social Movement Theory, ed. Aldon D. Morris and Carol M. Mueller (New Haven: Yale University Press, 1992). 
In every case study on genocide we can identify the workings of such frames. In Cambodia, for example, the Khmer Rouge revitalized (at least in part fictional) images of a glorious past during the Kingdom of Angkor, blended it with Marxist-Leninist ideas and preyed upon anti-Vietnamese and anti-Chinese resentments that were widespread in Cambodia. Combined with stressing selfreliance and the need to forge a new socialist man living a rural, communal life, the Khmer Rouge developed a new interpretative schema for Cambodia and the world. Based on this thinking, the communist cadres developed a cognitive frame that would support mass murder and genocide which basically consisted of a narrative, a mental map of a nation under threat by a whole series of enemies - counterrevolutionaries, US-imperialists, spies and saboteurs, Vietnamese traitors.

The Nazi story of their so-called Aryan master race threatened by what they perceived as Jewish bolshevism and in dire need of Lebensraum is another well-known example in this regard. Hitler and his followers constructed a frame that was based on a crude mixture of racism, eugenics, Nordic and Germanic mysticism, social Darwinism and several other ideas. From this worldview sprung a genocidal frame that singled out the perceived enemies of the self-proclaimed Aryans (especially the Jews) and those who were not worthy of inclusion in the new society (unwertes Leben, Asoziale etc.). In other parts of the world and at other times in history, leaders and perpetrators used other narratives and cognitions to frame their crimes. But while they all differ in their specific appearance, they nonetheless all serve some common purposes. In all of these and other cases of macro violence, these new frames abetted the necessary transformation of deviant behaviour (e.g. murder) into expected behaviour. ${ }^{31}$ In order to deal with the psychological consequences of difficult life conditions, frames encompassed what Staub calls "differentiation of ingroup and outgroup (...); just-world thinking (...); and scapegoating." ${ }^{32}$

So the joint action context necessary for the collective action of a state-sponsored social movement can be thought of as a frame, here: a genocidal frame. As such a frame establishes itself in the realm of the cognitive, it comes natural to also locate intent here. Out of the sociopsychological processes Staub describes, fuelled by ideology and bigot narratives, grows the will to exterminate human beings just for their (real or imagined) affiliation to a certain group. ${ }^{33}$ However, as Mann already convincingly argued, we need to take into consideration that intent is rarely there from the start: "Murderous cleansing is rarely the initial intent of perpetrators. It is rare to find evil geniuses plotting mass murder from the very beginning." ${ }^{34}$ In a similar vein, Verdeja argues for the concept of an "emerging intentionality." 35 The theoretical reflection on genocide through the eyes of frame analysis supports these perspectives. A frame is not something that is created at one point in time and then keeps a static existence. In fact, framing "is active in the sense that something is being done, and processual in the sense of a dynamic, evolving process." ${ }^{36}$ So we need to register that the intent to commit genocide arises in a frame that precedes it and marks a certain (but important) point in a longer framing process. Thus, as this frame develops prolonged periods of discrimination leading up to genocide occur, such as the anti-Jewish racial legislation in the 1930s in Nazi Germany only then culminating in the subsequent formalisation of the genocide process in the Holocaust. Also, in the run-up to the Rwandan genocide, the programmes broadcast on Radio-Télévision Libre des Milles Collines demonstrate how a genocidal frame can gradually emerge. In the late Ottoman empire, the increasing discrimination against the Armenians and their exclusion from the rights of Ottoman citizens, from the Hamidian massacres of 1894-96 into the early twentieth century, also leads to the 1914 document dubbed "The Ten Commandments" which spelled out the plan for genocide as it then subsequently unfolded.

Furthermore, complex cognitive patterns like a frame are never fully controlled by a single actor and are subject to constant reformulations and reformations, at least on a small scale.

\footnotetext{
${ }^{31}$ Jäger, Makrokriminalität.

${ }^{32}$ Ervin Staub, The Roots of Evil. The Origins of Genocide and Other Group Violence (Cambridge, UK: Cambridge University Press, 1989), 17.

${ }^{33}$ Ibid.

${ }^{34}$ Mann, The Dark Side of Democracy, 7; Shaw, What is genocide, 84.

${ }^{35}$ Verdeja, The Political Science of Genocide, 316.

${ }^{36}$ Snow and Benford, Framing Processes and Social Movements, 614.
} 
Although as a social phenomenon frames do have a life of their own, individual people and groups can systematically intervene and assert influence in its construction e.g. by using the media or other means for propaganda. In the context of state-sponsored movements, this is usually executed through the state apparatus. ${ }^{37}$ As Ambos shows in his criminological statements it is only on the state level that we find the "mastermind, leader, and planner", the "top-level actors" of genocide. ${ }^{38}$ We complement his remarks by adding that their genocidal intent manifests itself in frames that are crucial to constituting a social movement that actually executes the will to extermination. So intent does not magically and automatically arise, but is subject to the agency of individuals at some point in the framing process.

We now have established how intent develops and manifests itself on the macro level. The crucial question that subsequently arises is of course how this relates to the micro level of actual perpetration.

\section{Framing and the Possibility of Genocide: the Macro-Micro Bridge}

The emergence and development of genocidal frames should not be confused with the occurrence of actual genocide. While both are connected, as we will show in the following, we should not assume a strict causal relationship between them. Framing just makes the 'crime of crimes' possible. This becomes clear when we take a further look at the condition of frames and the options for action by the actors (the individual possible perpetrators).

First of all, we should note that frames seldom remain undisputed and uncontested. Almost always do alternative narratives of and solutions to perceived injustices and problems exist. While the context in which an individual is located and the offered genocidal frame are relatively stable across people in various concrete situations around the country, it is not said that the context is seen uniformly by the actors and it is possible for alternative frameworks of reference to be available to the individual in question. What may result is "boundary framing", "adversarial framing" and even "counterframing" ${ }^{39}$ It follows that we need to be aware of challenges to the framing initiatives of state actors, leaders and elites when analysing the dynamics of genocide. ${ }^{40}$ They need to establish "frame resonance" - conciliating the cognitive frameworks "with the current life situation and experience of the potential constituents." ${ }^{41}$ Thus, the genocidal intent also needs to be mediated and in some sense sold to the target audience.

Second, individual actors act in actual situations. The general genocidal context manifests itself in concrete situations ${ }^{42}$ and the individual finds himself or herself located within the joint action context - characterized by genocidal frames - as described above. An individual can find him or herself in a situation of genocidal possibility and then has to react to and within this situation and the opportunity structure which it offers. We need to take into account that individuals in the state-sponsored social movement do not automatically follow all aspects of frames and fully share its core components. This is of course important to our reflections on intent as it suggests that the common movement participants - the "ordinary men" - do not necessarily need to share this intent and may act due to different motivations than state actors and elites. From a sociological perspective, it is theoretically implausible to assume that framed genocidal intent is contagious

\footnotetext{
${ }^{37} \mathrm{Su}$, State-Sponsored Social Movements.

${ }^{38}$ Ambos, Criminologically Explained Reality of Genocide, 164.

${ }^{39}$ Snow and Benford, Framing Processes and Social Movements, 616-617.

${ }^{40}$ Of course, an intended dynamic towards genocide in a framing process may very well be initiated 'from below'. We do not want to add to the myth of elites deceiving innocent masses and luring them into genocide. Social movements and their participants should not be given carte blanche for instigating genocide. Having said this, however, we should keep the crucial role of state actors in mind when we talk about genocide.

${ }^{41}$ Snow et al., Frame Alignment Processes, 477.

${ }^{42}$ Situations are the concrete spatial and temporal environment in which individuals are actually located, which they perceive, in which they interact with others and in which their actual actions occur. Situations can be seen as the 'immediate environment', which Samuel Tanner defines as 'includ[ing] the social sphere to which the actor considers himself affiliated to, or belonging to', thus, often bringing together people who share certain frames, beliefs or attitudes. See Samuel Tanner, "Towards a Pattern in Mass Violence Participation? An Analysis of Rwandan Perpetrators' Accounts from the 1994 Genocide," Global Crime 12, no. 4 (2011).
} 
in a way that every movement participant will unanimously and immediately adopt it. Thus, when assessing the analytical value of and theoretical importance of intent in the perpetration of genocide, it is important to look at the context from the perspective of the individual, to see what frames they perceive and are acting in the context of.

To conclude, if we take these considerations into account, we need to retain that the development of a genocidal frame creates the possibility of genocide but not necessarily the actual execution of genocide. The formation of a genocidal frame is a necessary precondition for the formation of a genocidal movement that then in turn might engage in mass murder and other practices that put the genocidal intent into action. The possibility of genocide rises with the elaboration of the frame and increased frame resonance but should not be seen as an automatism.

In practice, this is one of the many gateways for genocide prevention. Here, however, in the context of our theoretical and conceptual remarks, we have reached a point where we need to leave the macro level and look at the motivations of the "ordinary men". How do they relate to genocidal frames, and what informs their actions to commit the atrocities?

\section{Genocidal Frame Reception: How Individuals Perceive Genocidal Intent}

When contemplating why people participate in this genocidal social movement, the general genocidal context manifests itself in concrete situations and the individual finds himself or herself located within the larger context of the genocidal frame and the genocidal possibilities this provides. Thus, our focus now moves from the national level to the individuals and the individuals' understanding of the broader context and the concrete situation in which they finds themselves. People can only act upon the information that they have on the situations they are in and here people are not entirely autonomous actors, but are embedded in a situation and particularly in multiple social relationships. Due to time limitations and limited cognitive resources, the normal strategy often is not to examine the details of any situation oneself, but to rely on the perceived judgements of influential others in one's environment whom one trusts and sees as authoritative on these issues; this could be people in positions of authority or peers. ${ }^{43}$ Not only does this strategy free one of the cognitive exertions of having to make one's own decision, but it also minimises the risk of ostracism from or ridicule by the group if one acts in discordance with the group. In the context of military or paramilitary groups, people will refer to what they believe their comrades or superiors believe about their situations, while civilians will also take into account not just political and social leaders, but also their friends and family.

This imitation of the beliefs of others around one, however, can lead to everyone taking on a similar frame and following this in action. Though only a minority may in fact believe in the frame, no-one questions it, and thus, individuals just assume that everyone else is in accordance with this frame. This state of what might be called pluralistic ignorance allows a minority to define which frame is chosen by the majority of the social movement. If many perpetrators believe that their compatriots are all ideologically supportive because of their actions and are, thus, adhering to a specific frame, they may also choose this frame. Because of the fear of ingroup repercussions, no individual speaks out against this in the assumption that the rest are a homogenous group, thus, making it possible for an overwhelming majority who do not actually support the genocidal norms to still act within the frame which stipulates genocidal intent and corresponding action. ${ }^{44}$ This effect is strengthened more because for most people this setting is novel and "people cannot call on previous guidelines for their new behavioural options", ${ }^{45}$ awarding the perceived group's consensus an even higher effect and raising fears of potentially being excluded from the group if one were to diverge from this consensus.

To what degree a person accepts the frame presented to him depends not only on his or her peers and beliefs on whether these peers also accept the frame. Instead individuals must hold the sources from whence the opinion has been propagated to be genuinely credible and reliable. This

\footnotetext{
${ }^{43}$ Jens Rydgren, "Beliefs," in The Oxford Handbook of Analytical Sociology, ed. Peter Hedström and Peter Bearman (Oxford: Oxford University Press, 2009), 83.

${ }^{44}$ Ibid., 84.

${ }^{45}$ Philip Zimbardo, The Lucifer Effect: Understanding How Good People Turn Evil (New York: Random House, 2008$), 212$.
} 
credibility can be enhanced when the frame is disseminated by "significant, epistemic authorities who are deemed trustworthy by members of a social group." 46 These could be also be termed what Jacques Sémelin calls "identity entrepreneurs" who "aim to show that the core of the [perpetrator ingroup's] problem-and therefore its solution-resides in the affirmation of their group's identity in the face of a threat from another group." ${ }^{47}$ These actors, thus, prepare a more fertile ground for the intent to destroy to manifest itself. In other words, they are more likely to achieve a significant threshold of frame resonance.

Further, as already mentioned above, in order to strengthen frame resonance, they must resonate with potential perpetrators' broader perception of the world, society or historical facts, that is, ideological statements regarding the intent to act out genocidal destruction must fit well into the master frame ${ }^{48}$ within which the individual is acting. Practically this means that a subtle acceptance of the premise of intent can create a permissive environment for the annihilation of the victim group, without the perpetrator even thinking of their perception of the victim group as ideologically influenced, much as people seldom reflect on the moral fabric of the society in which they live.

Altogether we see that in order to understand the role of intent it is important to look at how the message is received by the individuals themselves, to see whether the frame resonates with them, how they perceive the ideologies themselves. Even if something is propagated strongly at the macro level, there is no guarantee that it will arrive in this form or at all with the individual on the micro level. The next section will now look at how the individuals take this frame on board and how it does (or does not affect) affect their decisions on participating in the mass endeavour of genocide.

\section{Doing the Deed: How Individuals Come to Actually Participate in the Genocide}

It is within this micro-level situation, the immediate environment of the individual, that an individual makes his or her action decisions on whether to participate in the unfolding dynamics of violence or not. Here it is the motivation which an individual has which propels him or her into action, or conversely to not act at all. Finding themselves in a certain context and a specific situation, frames, including the one stipulating the necessity of genocidal action and including the intent to destroy the victim group, help people to make sense of their environment. In this clarification they also support the process of deciding between socially structured and individually constructed choices of action. ${ }^{49}$ Here, motivations become active as they guide a person in choosing an alternative for action. What we label as motivations here are what others have called situational mechanisms that create a link between the individual and the environment they are embedded in and, thus, guide a decision-making process..$^{50}$

It is important to note that an individual can only choose between alternatives which he or she actually perceives, not any which lie beyond the horizon of their imagination and framing. Nonetheless, individuals will in all situations perceive multiple possibilities for how they can act, even when they are being strongly coerced or see few alternatives, as it is precisely the alternatives (consequences of non-participation) which can make people want to participate. So when a Khmer Rouge cadre says "whether they wanted to do it or not, they must do it" what he actually means is "if they did not do it, they were also killed." ${ }^{51}$ Although the individual is portraying the action

${ }^{46}$ Jonathan Leader Maynard, “Rethinking the Role of Ideology in Mass Atrocities," Terrorism and Politcal Violence 26, no. 5 (2014), 821-841.

${ }^{47}$ Jacques Sémelin, Purify and Destroy: The Political Uses of Massacre and Genocide (New York: Columbia University Press, 2005), 84; Lee Ann Fujii, Killing Neighbours: Networks of Violence in Rwanda (Ithaca: Cornell University Press, 2009$), 4$.

${ }^{48}$ Master frames are more generic, wider, and of greater social range than certain frames of specific movements. See Snow and Benford, Framing Processes and Social Movements, 614.

${ }^{49}$ Peter Hedström and Lars Udehn, "Analytical Sociology and Theories of the Middle Range," in The Oxford Handbook of Analytical Sociology, ed. Peter Hedström and Peter Bearman (Oxford: Oxford University Press, 2009).

${ }^{50}$ Per-Olof H. Wilkström and Kyle H. Treiber. "Violence as Situational Action," International Journal of Conflict and Violence 3, no. 1 (2009).

${ }^{51}$ Quoting a former Khmer Rouge cadre who was chief of the commune chhlop [militia] and later chief of the collective committee (interview conducted by one of the authors in August 2015 in Kampong Chhnang Province, Cambodia). 
as inevitable and saying there are no alternatives, at the same time he is acknowledging that there is one (extremely unattractive) alternative which is refusing action and risking death. In the end, which of the perceived action alternatives an individual chooses is decided by whether an individual has a motivation for or against particular alternatives; these motivational orientations are weighed against each other and a person will only participate in genocidal action if they believe their motivations to be more strongly in favour of participation, outweighing the downsides of this participation.

Early research on motivations for participation in genocide postulated that participation could be best explained by certain personal dispositions and individual characteristics of the individuals who participate and a propensity to follow a genocidal ideology. ${ }^{52}$ Later Goldhagen controversially asserted strong claims that a majority of German policemen, soldiers and other functionaries were - as Germans - supportive of an eliminationist antisemitism and, thus, in favour of exterminating the Jews..$^{53}$ However, most research since has demonstrated that these individualistic and dispositional, as well as ideological explanations are reductionist and that perpetrators' characters are not individually aberrant nor are they ideologically different from many of their peers, but instead overwhelmingly normal. ${ }^{54}$ Instead, the situation in which an individual is embedded has a significant impact on decisions to participate - Newman stipulates the need to explain participation in genocide from an interactionist perspective which sees participation decisions as resulting both from personal dispositions in reaction to the situation, as well as the result of specific situations which have an impact on specific types of individuals. ${ }^{55}$ Consequently and importantly in the context of this article, the motivation does not need to be based on the ideology which stipulates the intent to destroy the victim group as provided in the frame propagated by the regime. This ideology can play a role for the individual, but does not have to. Instead there are a multitude of motivations which can lead to participation and these have been synthesised into an interdisciplinary model by Williams, who has attempted to break down the broad literature from several disciplines into just eleven distinct motivations. ${ }^{56}$ Williams differentiates between ingroupfocused, outgroup-focused and intrinsic motivations and here we will provide a short overview of the motivations in his model, referring them back to other parts of the literature.

Ingroup-focused motivations revolve around the perpetrators' social group, social dynamics within this group and social influence exhibited in these relations. Social influence occurs both vertically and horizontally, stemming from authorities and peers respectively, and can be tacit, explicit or laced with threats of force. The motivation which perpetrators cite most often themselves is obedience to the orders of an authority, as many believe this abdicates them from any responsibility for their actions, with this form of vertical influence conveyed either explicitly or tacitly. ${ }^{57}$ Further, social influence also works horizontally. Tacitly such horizontal social influence motivates people to participate through a desire for conformity with the other members of their ingroup and this has been demonstrated impressively in social psychological experiments by Asch. ${ }^{58}$ Horizontal influence can also be more explicitly and actively exerted by other members of the ingroup through peer pressure; these dynamics were seen widely in Rwanda and Bosnia, ${ }^{59}$ with over $64 \%$ of Scott Straus' respondents citing in-group pressure as a motivation for their genocide

\footnotetext{
${ }^{52}$ Theodor W. Adorno et al., The Authoritarian Personality (New York: Harper \& Row, 1950).

${ }^{53}$ Daniel J. Goldhagen, Hitler's Willing Executioners: Ordinary Germans and the Holocaust (London: Abacus, 1996).

${ }^{54}$ See note 17 above.

${ }^{55}$ Leonard Newman, "What is a Social-Psychological Account of Perpetrator Behaviour? The Person versus the Situation in Goldhagen's Hitler's Willing Executioners," in Understanding Genocide: The Social Psychology of the Holocaust, ed. Leonard Newman and Ralph Erber (Oxford: Oxford University Press, 2002); Paul Wilson, „Do normal people commit genocide? Observations from the Cambodian trial of 'Duch,'” Psychiatry, Psychology and Law 17, no. 4 (2010).

${ }^{56}$ Williams, The Complexity of Evil.

${ }^{57}$ Scott Straus, The Order of Genocide: Race, Power, and War in Rwanda (Ithaca: Cornell University Press, 2006).

${ }^{58}$ Solomon Asch, "Effects of Group Pressure upon the Modification and Distortion of Judgments," in Groups, Leadership and Men: Research in Human Relations, ed. Harold S. Guetzkow (New York: Russell \& Russell, 1963).

${ }^{59}$ Natalija Bašić, “'You can't run away': Former Combat Soldiers and the Role of Social Perception in Coping with War Experience in the Balkans," in After Mass Crime: The Challenges of Rebuilding States and Communities Following Mass Violence, ed. Béatrice Pouligny et al. (Tokyo and New York: United Nations University Press, 2006).
} 
participation. ${ }^{60}$ Finally, both horizontal and vertical pressures can be reinforced by the threat or actual application of force: coercion can, thus, strongly motivate people to participate genocide. In Cambodia many former Khmer Rouge cadres speak of "being fearful for their security", ${ }^{61}$ a phrase commonly used when discussing the Khmer Rouge regime as people felt that their security and lives were constantly endangered, as they may commit mistakes inadvertently and, thus, be defined as the enemy. Empirically, various instances of genocide have provided significantly different degrees of how credible threats of coercion were, with no evidence ever having been found in a post-war judicial setting that a refusal to participate in the Holocaust ever meant that a German functionary was killed; further, in the Rwandan genocide there are many examples of how people managed to evade participation altogether or for strategies to be recruited into the group of perpetrators but not actually have to participate in the killings. ${ }^{62}$ Nonetheless, these narratives of the fear of threats are often widespread amongst perpetrators and can, thus, very well motivate individuals to participate in genocide.

The next group of motivation factors put forward by Williams identify the locus of perpetration impetus in some aspect of the self, independent of a person's ingroup and their outgroup (to which we will subsequently come). First, individuals may participate in pursuance of opportunistic, self-serving goals, such as receiving the opportunity to loot or rape, promote their career, settle personal or political scores. ${ }^{63}$ For example, while career progression (or the aversion of demotion) posed a significant motivation for people to participate in killing across all the cases discussed here, looting and rape was particularly prolific in the Rwandan, Balkan and Armenian genocides. Further, settling personal scores which were open from prior to the genocide under the auspices of the genocidal framework allowed people in Rwanda and Cambodia particularly to rid themselves of old foes.

Also, people with a penchant for sadism can seize the opportunity to participate, and while these people may not make up many in terms of numbers their excessive cruelty has been documented widely for many genocides ${ }^{64}$ Further, as with committing crimes or doing something else forbidden, the resulting excitement or thrills provide an impetus for participation. ${ }^{65}$ Some individuals assume alternative genocidal roles and start to conform to a new set of norms and practices associated with this role. ${ }^{66}$ Thus, in the Cambodian context, one cadre speaks about what it was like to join the Khmer Rouge: "When we joined, it was like we were entering into a tiger zone, so we had to be a tiger like them. So, we needed to be a tiger like them, to be cruel like them. No morality like them. That's why they were like that." ${ }^{67}$ This former militiaman uses the metaphor of the tiger and the tiger zone to express how he internalised the norms and values, as well as the behaviour he believed was expected of him in this role. Finally, the allure of status and power which are associated with participation can exert a strong pull on some individuals; a key motivation can be constituted by threats to someone's status or their $\mathrm{ego}^{68}$ or by the intensely satisfying experience of power over someone else. ${ }^{69}$ Using another Cambodian example in which status has been shown

\footnotetext{
${ }^{60}$ Straus, The Order of Genocide, 139.

${ }^{61}$ Multiple interviewees used this terminology in interviews conducted by one of the authors with fifty-nine former Khmer Rouge cadres between July 2014 and January 2015 in ten provinces of Cambodia.

${ }^{62}$ Ravi Bhavnani, "Ethnic Norms and Interethnic Violence: Accounting for Mass Participation in the Rwandan Genocide," Journal of Peace Research 43, no. 6 (2006); Herbert Jäger, Verbrechen unter totalitärer Herrschaft: Studien zur nationalsozialistischen Gewaltkriminalität (Frankfurt am Main: Suhrkamp, 1982), 84-93.

${ }^{63}$ Williams, The Complexity of Evil.

${ }^{64}$ C. Fred Alford, What Evil Means to Us (Ithaca: Cornell University Press, 1997), 28.

${ }^{65}$ Jack Katz, Seductions of Crime: Moral and Sensual Attractions in Doing Evil (New York: Basic Books, 1988), 53; Mark Warr, Companions in Crime: The Social Aspects of Criminal Conduct (Cambridge, UK: Cambridge University Press, 2002$), 82$.

${ }^{66}$ Donald Bloxham, “Organized Mass Murder: Structure, Participation, and Motivation in Comparative Perspective," Holocaust and Genocide Studies 22, no. 2 (2008).

${ }^{67}$ Quoting a former Khmer Rouge cadre who was first a member and later chief of the commune chhlop [miltia] (interview conducted by one of the authors in August 2015 in Battambang Province, Cambodia).

${ }^{68}$ Roy Baumeister, "The Holocaust and the Four Roots of Evil," in Understanding Genocide: The Social Psychology of the Holocaust, ed. Leonard S. Newman and Ralph Erber (Oxford: Oxford University Press, 2002).

${ }^{69}$ Jacques Sémelin, Purify and Destroy: The Political Uses of Massacre and Genocide (New York: Columbia University Press, 2005).
} 
to be particularly prominent as a motivation: "No, no-one wanted to stop; they were happy. In short, because they were in the unit, they had face."70

The last group of motivations focus on the outgroup of the perpetrators: the victims. First, emotions regarding the victims can certainly have an impact on motivating individuals to participation. This is particularly so with fear, resentment, hatred, anger and disgust allowing for situations to be framed so that people have psychological incentives to participate in genocidal actions against members of the victim group, as has been shown particularly for the Bosnian case. ${ }^{71}$ Next, genocidal ideologies can motivate participation as they stipulate the moral foundations of the destruction of the victim group and, thus, transport the genocidal intent discussed above. Such an ideology creates a frame within which it is the good, right and legitimate course of action and a necessary or inevitable pathway which needs to be followed, ${ }^{72}$ anti-Semitism, ${ }^{73}$ exclusive ideologies, ${ }^{74}$ toxification ${ }^{75}$ and many other types of ideologies have been discussed in the literature. ${ }^{76}$

Regarding the role of intent-the focus of this paper-the conclusions from this model are slightly sobering: only one of the eleven motivations proposed by Williams is inherently connected to the notion of genocidal intent: that of ideology. ${ }^{77}$ The other motivations all stipulate reasons why people would want to participate in the killing, not with the final aim of annihilating the victim group, but rather for the sake of participation.

As we have seen that genocidal intent only plays a part in some motivations, a key question that needs to be asked in order to fully comprehend the role and idea of intent at the micro level is that of individuals' knowledge of this macro level intent, as already suggested above. An individual lower down the hierarchy can 'be aware of the genocidal context and, thus, of the supporting nature of his conduct but he may not possess the purpose-based intent to destroy the respective group himself' ${ }^{78}$ This would mean that the individual has knowledge of the enterprise to which he or she is contributing even without the intention of this contribution being the destruction of the group. Rather, the many other motivations can be the reason someone participates, despite the knowledge of the consequences of his or her action in concert with the actions of many other people. This

\footnotetext{
${ }^{70}$ Quoting a former Khmer Rouge guard at a security centre, who later became the body guard and messenger for chief of the security centre (interview conducted by the author in August 2015 in Kandal Province, Cambodia). In the Cambodian context, having face means to have status, a concept which is defined individually according to many different criteria; the attainment of face is extremely important within Cambodian culture, thus making it an important motivation in individuals' actions. See Alexander Laban Hinton, Why Did They Kill? Cambodia in the Shadow of Genocide (Berkeley: University of California Press, 2005).

${ }^{71}$ Roger Petersen, Understanding Ethnic Violence: Fear, Hatred, and Resentment in Twentieth-Century Eastern Europe (Cambridge, UK: Cambridge University Press, 2002).

${ }^{72}$ For a more nuanced discussion of the function of genocidal ideologies see Leader Maynard, "Rethinking the role."

${ }^{73}$ Goldhagen, Hitler's Willing Executioners; Karin Orth, "Experten des Terrors. Die Konzentrationslager-SS und die Shoah," in Die Täter der Shoah: Fanatische Nationalsozialisten oder ganz normale Deutsche?, ed. Gerhard Paul (Göttingen: Wallstein, 2002), 93-108.

${ }^{74}$ Barbara Harff, "No Lessons Learned from the Holocaust? Assessing Risks of Genocide and Political Mass Murder since 1955," American Political Science Review 97, no. 1 (2003).

${ }^{75}$ Rhiannon S. Neilsen, "Toxification as a More Precise Early Warning Sign for Genocide than Dehumanisation? An Emerging Research Agenda," Genocide Studies and Prevention 9, no. 1 (2015).

${ }^{76}$ In Williams' model the motivations are complemented by facilitative factors and contextual conditions. Facilitative factors are not sufficient for causing someone to actually participate, but they make the participation significantly easier, and thus, also more likely. Contextual conditions are macro-level conditions, which set the framework within which the genocide can occur and which can also impact participation by making some motivations more salient than others. It would go beyond the scope of this paper, however, to present these in detail here. See note 18 above.

${ }^{77}$ Besides framing, transporting and advocating intent, ideologies can also impact participation in several other ways, which are seldom differentiated stringently from intent in the literature. Ideologies can help reduce cognitive dissonance within the perpetrator. Normally, people try to avoid behaviour which violates their moral standards, but cognitive dissonance arises when actions are misaligned with how individuals think they should be acting. See James Waller, Becoming Evil: How Ordinary People Commit Genocide and Mass Killing (Oxford: Oxford University Press, 2002). Ideologies can assist in combatting cognitive dissonance by disengaging the person's acts from the moral nature of the act of killing. Going further than just disengagement, ideologies can increase the moral appeal of the act of killing itself by justifying it as imperative and portraying it in a positive light. See Manuel Eisner, "The Uses of Violence: An Examination of Some Cross-Cutting Issues," International Journal of Conflict and Violence 3, no. 1 (2009).

${ }^{78}$ Ambos, Criminologically Explained Reality of Genocide, 166.
} 
participation is the tacit acceptance of the intent to destroy in its concrete manifestation, providing behavioural support, while refusing attitudinal support or remaining indifferent.

One empirical question remains, however, concerning whether it is possible for people to participate in genocidal actions without knowledge of the intent to destroy. When we reflect on much discussed perpetrators such as SS guards in Third Reich concentration camps who were involved in the gassing of millions of Jews, the answer is unequivocally negative, but as the bureaucratic and physical distance to the killing increases, perhaps so does the knowledge of the intent to destroy. While there may have been individuals who were not aware of the larger implications of their actions and the dynamics within which they were embedded, for most perpetrators in Rwanda, Cambodia and Armenia it will have been quite obvious that they were acting as part of a master plan of genocidal destruction.

Are these people legally or morally equally culpable? Does the knowledge of what one is participating in have normative implications for otherwise identical actions? Can people be held accountable for actions they had no intention of committing, that is for the crime of genocide even though they thought they were 'only' committing state-sanctioned murder? From a legal point of view they are not culpable unless dolus specialis is proven for every accussed, and we would argue that it is not necessary for these people to be understood as perpetrators of crimes of genocide (which would by definition stipulate intent) as it would suffice for them to be seen as just perpetrators of the individual crimes they commit. Nonetheless, from a sociological point of view one could equally label them as genocide perpetrators as the aggregation of their crimes (even without them individually having intent) still creates the genocidal outcome with or without their knowledge of the consequences of their actions. In the end it reduces them more still to tools of the political elite, who have agency only within their situations but have little impact on the broader societal dynamics of violence.

On the other hand, it is unlikely that a large number of people will participate in genocide without knowledge of the broader implications of their actions and the dynamics unfolding around them. This suspicion is supported up by the case of Cambodia in which the Khmer Rouge was notoriously secretive about their plans and whose recruits came from the most uneducated of the population, and were often very young. Nonetheless, the cadres of the regime knew very well what they were participating in, even if it was most often not their explicit intention to support this intent to destroy. All Khmer Rouge cadres knew what it meant to be an "internal enemy" and a "traitor of Ângkar", the party organisation of the Khmer Rouge. People were defined as an internal enemy quite easily by committing anything defined as a mistake by the Khmer Rouge, be it stealing food, not working hard enough, engaging in extra-marital affairs, or a plethora of other misdemeanours. It was perfectly clear to the cadres that being an enemy necessitated being killed, and that it was necessary for the good of the revolution that all internal enemies be killed.

\section{Genocide as the Aggregation of Individual Acts}

With these motivations individuals can commit acts against people of the victim group. As indicated above, there is no analytical consensus in the social-scientific literature on what constitutes an individual act of perpetration in the context of genocide and, thus, it is unclear how people actually participate. Individuals at the extreme end of the spectrum appear quite obvious in their categorisation: people who kill members of the victim group can be easily classed as perpetrators. However, it is unclear as to which further acts such as logistical assistance, arresting and transportation, vocal support or incitement can also be counted as perpetration. Legally these acts would be described as aiding and abetting genocide, but in the social-scientif study of perpetrators this complicated field has as yet not been addressed systematically. While it is certainly necessary for future research to discuss a more nuanced typology, it would go beyond the scope and aim of this paper to develop this here. Furthermore, for the argument we are making about the role of intent in the genesis of genocide at the macro and micro level, these differences in perpetration make little difference. These acts occur in concrete situations by specific individuals, but it is the summation of many of these acts across many situations that allows for genocide to manifest itself in reality. These acts together allow the victim group to be increasingly discriminated against, marginalised and ultimately to be killed, thus eliminating the group in whole or in part. 
This aggregation of multiple acts which eliminate the victim group constitutes the occurrence of genocide.

With the occurrence of genocide through myriad small acts of perpetration, by definition, the realisation of genocidal intent manifests itself. Usually thousands of different people work together towards the gruesome goal of annihilating a whole group of human beings, thereby adopting different roles and duties. Genocide occurs for various reasons, as "ordinary men", collaborators, the joiners act following a large variety of different motivations.

\section{Conclusion}

The purpose of this article was to develop a sociological conceptual perspective with a more nuanced view on the role of intent in genocide. Our starting point was to think of genocide as a social phenomenon, as collective action by a state-sponsored social movement that is working towards the destruction of a specific group as such, thereby being constituted and instructed by a collective frame. As we have further elaborated, elites and leaders develop genocidal intent in the process of framing, and realign the frame accordingly. The more the frame is in line with their other beliefs with them, the higher the chance that low-level perpetrators will act on their other motivations and join the movement. Frame resonance is increased when it is accepted by "identity entrepreneurs" and successfully linked to prevailing master frames. Low-level perpetrators might know of the intent of the elites, and if they are ideologically motivated actors, they might also share the beliefs of the elite. Social movement theory even allows acknowledging that genocidal frames might decisively be developed "from below." But as empirical findings suggest, most "ordinary men" join the movement and commit acts of cruelty for more simple reasons ranging from obedience to authority, coercion, and peer pressure, to sadism, opportunism or the allure of status and power.

So, on the one hand, genocidal intent certainly is an important step in the framing process. Regardless of when it actually emerges and manifests itself in the process, intent is what pushes elites and leaders to further consolidate and disseminate the frame (e.g. through propaganda). It also transforms what might otherwise be "just" a repressive and reactionary frame into a murderous one and allows the movement it informs to further radicalize itself. But while we should not downplay the role of genocidal intent to the point where it barely matters at all in our conceptualization of genocide and mass violence, we also should not overstate its impact. As we have shown above, genocidal intent can be realised without (direct) perpetrator intent. Those who intend to commit genocide do not need to convince everyone in a genocidal movement of their mission. They simply need to align the frame accordingly and, thus, create a context in which individual perpetrators act out of very different motives. Whether or not perpetrators have genocidal intent to commit genocide is essential for legal proceedings, but for the actual realisation of the genocidal campaign it is significantly less relevant.

Against the backdrop of these considerations and findings we want to encourage thinking beyond the liberal/post-liberal divide. Assuming a uniform conception of intent and a direct correlation (or even a causal relationship) between intent and the actual outcome of mass murder is certainly misleading. However, blurring the distinction between genocide and other occurrences of macro-level violence is also not an advisable solution. There are certain phenomena of mass atrocity where intent clearly is identifiable and might play a vital role in framing the context of a violent state-sponsored social movement. Our conceptual approach takes a middle ground that also cuts through the binary thinking of knowledge- and purpose-based approaches. Generally speaking, elites and leaders act purposefully when framing genocidal action at the macro level, while low-level perpetrators act mostly out of different motivations knowing what their superiors might have in mind at the micro level. Incorporating frame analysis into a theory of genocide, thus, offers a new perspective that pushes beyond some of the conceptual shortcomings of the current debate.

It would be worthwhile to clarify that it was beyond the scope of the article to discuss the ethical, legal and normative implications of our theoretical arguments. Rethinking the relevance of intent and other forms of motivation not only calls for a legal reconceptualization of genocidal intent. It also asks us to contemplate the status of genocide as the so-called crime of crimes and 
its distinction from other forms of mass atrocities. While genocide as a phenomenon of macro violence differentiates itself from other forms of mass killing through genocidal intent, this intent does not necessarily manifest itself in the individuals who implement the genocidal policies. Thus, at the individual level patterns of participation and perpetration should not be different between genocide and other forms of mass killing. At this level and beyond a legal framework, it might be more fruitful to resort more to the uniqueness of each case of macro violence or a more nominal scale of violence and escalation instead of thinking in clear categories like genocide and crimes against humanity. Further discussion is needed on what consequences this defining element of intent has on the men and women who participate in genocide. For this, further research must go beyond the conceptual clarification of the role of intent in genocide discussed in this article. ${ }^{79}$

\section{Bibliography}

Adorno, Theodor W., Else Frenkel-Brunswik, Daniel J. Levinson, and R. Nevitt Sanford. The Authoritarian Personality. New York: Harper \& Row, 1950.

Alford, C. Fred. What Evil Means to Us. Ithaca: Cornell University Press, 1997.

Ambos, Kai. "Criminologically Explained Reality of Genocide, Structure of the Offence and the 'Intent to Destroy' Requirement." In Collective Violence and International Criminal Justice: An Interdisciplinary Approach, edited by Alette Smeulers, 153-173. Antwerpen - Oxford Portland: Insertia, 2010.

Asch, Solomon. "Effects of Group Pressure upon the Modification and Distortion of Judgments." In Groups, Leadership and Men: Research in Human Relations, edited by Harold S. Guetzkow, 177-190. New York: Russell \& Russell, 1963.

Bašić, Natalija. "'You can't run away': Former Combat Soldiers and the Role of Social Perception in Coping with War Experience in the Balkans." In After Mass Crime: The Challenges of Rebuilding States and Communities Following Mass Violence, edited by Béatrice Pouligny, Simon Chesterman and Albrecht Schnabel, 142-163. Tokyo and New York: United Nations University Press, 2006.

Baumeister, Roy. "The Holocaust and the Four Roots of Evil." In Understanding Genocide: The Social Psychology of the Holocaust, edited by Leonard S. Newman and Ralph Erber, 241-258. Oxford: Oxford University Press, 2002. https://doi.org/10.1093/acprof:oso/9780195133622.003.0011

Bhavnani, Ravi. "Ethnic Norms and Interethnic Violence: Accounting for Mass Participation in the Rwandan Genocide." Journal of Peace Research 43, no. 6 (2006): 651-669. https://doi. org $/ 10.1177 / 0022343306069290$

Bloxham, Donald. "Organized Mass Murder: Structure, Participation, and Motivation in Comparative Perspective." Holocaust and Genocide Studies 22, no. 2 (2008): 203-245. https://doi.org/10.1093/hgs/dcn026

Browning, Christopher. Ordinary Men: Reserve Police Battalion 101 and the Final Solution in Poland. New York: Harper, 1993.

Card, Claudia. "Genocide and Social Death." Hypatia 18, no. 1 (2003): 63-79. https://doi. org/10.1111/j.1527-2001.2003.tb00779.x

Eisner, Manuel. "The Uses of Violence: An Examination of Some Cross-Cutting Issues." International Journal of Conflict and Violence 3, no. 1 (2009): 40-59.

Fujii, Lee Ann. Killing Neighbours: Networks of Violence in Rwanda. Ithaca: Cornell University Press, 2009.

Goffman, Erving. Frame Analysis: An Essay on the Organization of Experience. Boston: Northeastern University Press, 1986.

Goldhagen, Daniel J. Hitler's Willing Executioners: Ordinary Germans and the Holocaust. London: Abacus, 1996.

Harff, Barbara. "No Lessons Learned from the Holocaust? Assessing Risks of Genocide and Political Mass Murder since 1955." American Political Science Review 97, no. 1 (2003): 57-73. https://doi.org/10.1017/S0003055403000522

\footnotetext{
${ }^{79}$ Nearly all interviewees followed this construction of internal enemies and were aware that being an internal enemy necessitated their killing within the Khmer Rouge regime; demonstrated in most of the aforementioned interviews.
} 
Hedström, Peter, and Lars Udehn. "Analytical Sociology and Theories of the Middle Range." In The Oxford Handbook of Analytical Sociology, edited by Peter Hedström and Peter Bearman, 25-47. Oxford: Oxford University Press, 2009.

Hinton, Alexander Laban. Why Did They Kill? Cambodia in the Shadow of Genocide. Berkeley: University of California Press, 2005.

Jäger, Herbert. Verbrechen unter totalitärer Herrschaft: Studien zur nationalsozialistischen Gewaltkriminalität. Frankfurt am Main: Suhrkamp, 1982.

Jäger, Herbert. Makrokriminalität: Studien zur Kriminalität kollektiver Gewalt. Frankfurt am Main: Suhrkamp, 1989.

Jensen, Olaf. "Evaluating Genocidal Intent: The Inconsistent Perpetrator and the Dynamics of Killing." Journal of Genocide Research 15, no. 1 (2013): 1-19. https://doi.org/10.1080/1462352 $\underline{8.2012 .759396}$

Katz, Jack. Seductions of Crime: Moral and Sensual Attractions in Doing Evil. New York: Basic Books, 1988.

Kimura, Akio. "Genocide and the Modern Mind: Intention and Structure." Journal of Genocide Research 5, no. 3 (2003): 405-420. https://doi.org/10.1080/1462352032000154633

Leader Maynard, Jonathan. "Rethinking the Role of Ideology in Mass Atrocities." Terrorism and Politcal Violence 26, no. 5 (2014): 821-841. https://doi.org/10.1080/09546553.2013.796934

Longerich, Peter. Holocaust. The Nazi Persecution and Murder of the Jews. Oxford: Oxford University Press, 2010.

Mann, Michael. The Dark Side of Democracy: Explaining Ethnic Cleansing. Cambridge, UK: Cambridge University Press, 2005.

Moses, A. Dirk. "Conceptual Blockages and Definitional Dilemmas in the 'Racial Century': Genocides of Indigenous Peoples and the Holocaust." Patterns of Prejudice 36, no. 4 (2002): 7-36. https://doi.org/10.1080/003132202128811538

Neitzel, Sönke. Abgehört: Deutsche Generäle in britischer Kriegsgefangenenschaft, 1942-1945. Berlin: Propyläen, 2005.

Newman, Leonard. "What is a Social-Psychological Account of Perpetrator Behaviour? The Person versus the Situation in Goldhagen's Hitler's Willing Executioners." In Understanding Genocide: The Social Psychology of the Holocaust, edited by Leonard Newman and Ralph Erber, 43-67. Oxford: Oxford University Press, 2002.

Neilsen, Rhiannon S. "Toxification as a More Precise Early Warning Sign for Genocide than Dehumanisation? An Emerging Research Agenda." Genocide Studies and Prevention 9, no. 1 (2015): 83-95. https://doi.org/10.5038/1911-9933.9.1.1277

Orth, Karin. "Experten des Terrors. Die Konzentrationslager-SS und die Shoah.“ In Die Täter der Shoah: fanatische Nationalsozialisten oder ganz normale Deutsche?, edited by Gerhard Paul, 93108. Göttingen: Wallstein, 2002.

Owens, Peter B., and David A. Snow. "Genocide and Social Movements." In The Wiley-Blackwell Encyclopaedia of Social and Political Movements, edited by David A. Snow, Donatella Della Porta, Bert Klandermans, and Doug McAdam. Oxford: John Wiley \& Sons, 2013. https://doi.org/10.1002/9780470674871.wbespm466

Paul, Gerhard. Die Täter der Shoah: Fanatische Nationalsozialisten oder ganz normale Deutsche? Göttingen: Wallstein Verlag, 2002.

Petersen, Roger. Understanding Ethnic Violence: Fear, Hatred, and Resentment in Twentieth-Century Eastern Europe. Cambridge, UK: Cambridge University Press, 2002. https://doi.org/10.1017/ CBO9780511840661

Powell, Christopher. “What Do Genocides Kill? A Relational Conception of Genocide.” Journal of Genocide Research 9, no. 4 (2007): 527-547. https://doi.org/10.1080/14623520701643285

Rydgren, Jens. "Beliefs." In The Oxford Handbook of Analytical Sociology, edited by Peter Hedström and Peter Bearman, 72-93. Oxford: Oxford University Press, 2009.

Schabas, William A. Genocide in International Law: The Crimes of Crimes. 2nd ed. Cambridge, UK: Cambridge University Press, 2009. https://doi.org/10.1017/CBO9780511575556

Schabas, William A. An Introduction to the International Criminal Court. Cambridge, UK: Cambridge University Press, 2011. https://doi.org/10.1017/CBO9780511975035 
Sémelin, Jacques. Purify and Destroy: The Political Uses of Massacre and Genocide. New York: Columbia University Press, 2005.

Shaw, Martin. What is Genocide?. Cambridge, UK and Malden: Polity Press, 2007.

Snow, David A. "Framing Processes, Ideology, and Discursive Fields." In The Blackwell Companion to Social Movements, edited by David A. Snow, Sarah A. Soule, and Hanspeter Kriesi, 380412. Malden: Blackwell, 2004. https://doi.org/10.1002/9780470999103

Snow, David A., and Robert D. Benford. "Master Frames and Cycles of Protest." In Frontiers in Social Movement Theory, edited by Aldon D. Morris and Carol M. Mueller, 133-155. New Haven: Yale University Press, 1992.

Snow, David A., and Robert D. Benford. "Framing Processes and Social Movements: An Overview and Assessment." Annual Review of Sociology 26 (2000): 611-639. https://doi.org/10.1146/ annurev.soc.26.1.611

Snow, David A., Robert D. Benford, Steven K. Worden, and E. Burke Rochford Jr. "Frame Alignment Processes, Micromobilization, and Movement Participation." American Sociological Review 51, no. 4 (1986): 464-481.

Staub, Ervin. The Roots of Evil: The Origins of Genocide and Other Group Violence. Cambridge, UK: Cambridge University Press, 1989.

Straus, Scott. The Order of Genocide: Race, Power, and War in Rwanda. Ithaca: Cornell University Press, 2006.

Su, Yang. "State-Sponsored Social Movements." In The Wiley-Blackwell Encyclopedia of Social Movements, edited by David A. Snow, Donatella Della Porta, Bert Klandermans, and Doug McAdam. Oxford: John Wiley \& Sons, 2013. https://doi.org/10.1002/9780470674871. wbespm395

Tanner, Samuel. "Towards a Pattern in Mass Violence Participation? An Analysis of Rwandan Perpetrators' Accounts from the 1994 Genocide." Global Crime 12, no. 4 (2011): 266-289. https://doi.org/10.1080/17440572.2011.616054

Tarrow, Sidney. Power in Movements: Social Movements and Contentious Politics. 2nd ed. Cambridge, UK: Cambridge University Press, 2008.

Totten, Samuel, and Paul R. Bartrop Dictionary of Genocide. Westport and London: Greenwood Press, 2008.

United Nations. Convention on the Prevention and Punishment of the Crime of Genocide, December 9, 1948. UN Doc. A/RES/260(III)[A-C].

Verdeja, Ernesto. "The Political Science of Genocide: Outlines of an Emerging Research Agenda." Perspectives on Politics 10, no. 2 (2012): 307-321. https://doi.org/10.1017/S1537592712000680

Waller, James. Becoming Evil: How Ordinary People Commit Genocide and Mass Killing. Oxford: Oxford University Press, 2002.

Warr, Mark. Companions in Crime: The Social Aspects of Criminal Conduct. Cambridge, UK: Cambridge University Press, 2002. https://doi.org/10.1017/CBO9780511803956

Wilkström, Per-Olof H., and Kyle H. Treiber. "Violence as Situational Action." International Journal of Conflict and Violence 3, no. 1 (2009): 75-96.

Williams, Timothy. "The Complexity of Evil: A Multi-Faceted Approach to Genocide Perpetration." Zeitschrift für Friedens- und Konfliktforschung 3, no. 1 (2014): 71-98.

Wilson, Paul. "Do normal people commit genocide? Observations from the Cambodian trial of 'Duch"'. Psychiatry, Psychology and Law 17, no. 4 (2010): 495-502. https://doi. org $/ 10.1080 / 13218711003739060$

Zimbardo, Philip. The Lucifer Effect: Understanding How Good People Turn Evil. New York: Random House, 2008. 